\title{
INVESTIGATION OF INLAND POLLUTION USING TOTAL CARBON (TC), TOTAL ORGANIC CARBON (TOC), INORGANIC CARBON (IC), TOTAL NITROGEN (TN) AND TOC/TN RATIOS
}

\author{
DINÇER, A. R. $.^{*}-$ YÜMÜN, S. ${ }^{2}-$ ÖNCE, M. ${ }^{3}-$ YÜMÜN, Z. Ü. ${ }^{1}$ \\ ${ }^{1}$ Department of Environmental Engineering, Namık Kemal University, Corlu, Tekirdağ, Turkey \\ (e-mail: zyumun@nku.edu.tr) \\ ${ }^{2}$ Saray Vocational High School, Poliza Endüstri A.Ş Çerkezköy, Tekirdă̆, Turkey \\ (e-mail:sevinc.yumun@gmail.com) \\ ${ }^{3}$ Namık Kemal University, Corlu, Tekirdă̆, Turkey \\ (e-mail:melike21once@gmail.com) \\ *Corresponding author \\ e-mail:adincer@nku.edu.tr \\ (Received $12^{\text {th }}$ Jun 2019; accepted $25^{\text {th }}$ Oct 2019)
}

\begin{abstract}
In this study, sediment samples were taken at three different points in Edremit Bay at different depths from the sea floor. In Edremit Bay, it was investigated whether the pollution was marine or terrestrial. According the results of measurement of TOC (Total Organic Carbon) values have been yielded results between 10.35-20.36 (Küçükkuyu), 8.14-16.40 (Güre), and 2.71-12.60 g/kg (Dikili) in the marine sediments. The fact that first and second regions are susceptible to mountainous and intra-continental erosion (sedimentation 5.743 and $7.509 \mathrm{~mm} /$ year) increased the TOC value. The highest TOC/TN ratio (12.33-46.89) was found in the second region. No linear change in TOC and TOC/TN (Total Nitrogen) ratios was observed at all three points depending on the depth. At results of compared all carotes, the low TOC/TN (2.82-14.48) ratio have been observed in the BH1 carotes, probably the result of small stream beds and low intra-continental erosion. This study shows that TOC and TOC/TN ratios in different parts of Edremit Gulf show inconsistency and this inconsistency arises not only from the marine contribution their natural organic matter, but also from the continent.
\end{abstract}

Keywords: inland pollution, marine pollution, TOC, TN, TOC/TN

\section{Introduction}

In this study, total organic carbon (TOC), inorganic carbon (IC), total carbon (TC) and total nitrogen (TN) concentrations in the sea sediments of Edremit Bay (Balıkesit/Turkey) were investigated. Stable isotopes, such as carbon $(\mathrm{C})$ and nitrogen $(\mathrm{N})$, are the tools used to assess the geochemical processes in the environment and to determine the anthropogenic effect. $\mathrm{C}$ and $\mathrm{N}$, the major constituents their organic matter, can bear the footprints of their hydrological flows and sediment processes, including anthropogenic modifications in the natural system (Zetsche et al., 2011; De Souza et al., 2017). Elemental composition and $\mathrm{C} / \mathrm{N}$ ratios are frequently used as markers for organic carbon sources in sediments (Jacob et al., 2009). Soil, sediments, organic carbon, and nitrogen are mainly the result of the decomposition of plants and animals or plankton or anthropogenic sources such as chemical contaminants, fertilizers, or organic-rich wastes (Avramidis et al., 2015). Hydrocarbons in sediments are considered effective tracers because they correlate well with the sources of their formation (Meyers et al.,1984). The atomic TOC/N ratio separates the organic matter from marine or terrestrial. The terrestrial organic matter is enriched in carbon relative to nitrogen and shows a high TOC/N ratio 
(Hecky et al., 1993). Terrestrial plants are rich in cellulose, and algae contain nitrogenrich compounds. The TOC/N ratio of terrestrial organics ranges from 12 to 14 (Meyers et al., 1984). TOC/N ratios in vascular land plants and mangrove leaves were higher than 20 (Lallier-Verges et al., 1998; Azevedo, 2003). If the TOC/N ratio is between 6 and 8, it reflects the nature of planktonic marine origin organic matter (Venkatesan et al., 1987). An intermediate value of $\mathrm{TOC} / \mathrm{N}=10$ reflects the characteristic of the mixing zones between marine and terrestrial sources (Stein, 1991). Allochthonous (ice-fed) and autochthonous (in-situ) carbonates can be distinguished by assuming that carbonates are glacial or biogenic in their origin and that the organic matter is biologically derived (organic carbon is negligible in glacial source material) (Koziorowska et al., 2016). TOC value varies between $1 \mathrm{mg} / \mathrm{L}$ in sea waters, $2-10 \mathrm{mg} / \mathrm{L}$ in lake or river waters, and up to $10 \mathrm{~g} / \mathrm{L}$ in swamps (Bayram et al., 2011). Accumulation of OC in marine sediments as a result of biological degradation is known to contribute significantly to the reduction of atmospheric $\mathrm{CO}_{2}$. Changes in total alkalinity increase or decrease $\mathrm{CO}_{2}$ emissions from the atmosphere. In contrast, the formation of biogenic carbonates reduces alkalinity and leads to the opposite effects (Koziorowska et al., 2016). Most of the metals in the aquatic systems are associated with the particle phase, and more than $99 \%$ of the pollutants are present in fine-grained precipitates in complex with organic matter and oxides (Bartoli et al., 2012; Martínez-Santos et al., 2015).

In the marine environment, organic matter $(\mathrm{OM})$ is composed of compounds that are resistant to biochemical oxidation. In non-contaminated natural waters, TOC results from humic substances and partially degraded plants or animal substances (Visco et al., 2005; Bayram et al., 2011). In a study conducted by Yümün and Önce (2017), heavy metal pollution and foraminiferal populations were determined in the samples obtained from the sea floor soundings in Küçükkuyu (Çanakkale) region. Refractory compounds (humic and fulvic acids), structural carbohydrates, and black carbon usually form the majority of sedimentary organic matter and are often brought to sea from land (Winogradow et al., 2018). $\mathrm{C}_{\mathrm{org}} / \mathrm{TN}$ ratios indicate the greater availability of paleolakes-combined nitrogen and possibly loading of algae-derived organic matter. In order to understand biogeochemical cycles, the formation of organic matter and accumulation in sediments are very important (Waterson et al., 2008; Sampaio et al., 2010). The results of studies to date show that $60-80 \%$ of $\mathrm{C}_{\text {org }}$ originates from land (allochthonous), but other studies show that marine organisms play an important role in OM in sediments (Koziorowska et al., 2016).

In this study, analyses of the total carbon (TC), the total inorganic carbon (IC), the total nitrogen $(\mathrm{TN})$, and $\mathrm{C} / \mathrm{N}$ were performed in the sludge samples taken from the seabed. It was concluded that the inland pollution dominated in the sediment samples taken from the sea floor in the Küçükkuyu, Güre, and Dikili regions.

\section{Material and Methods}

In the Bay of Edremit (Güre, Küçükkuyu, and Dikili), three drillings with an average depth of $20 \mathrm{~m}$ were made using a pontoon drilling machine that was modularly constructed on the sea. The sediment cores obtained from the drillings were preserved in special core boxes and analyzed in this study. The depth of the samples was calculated from the top of the sediments.

The Dikili district is located on the northern coast of the Aegean Region in the west of the Aegean Sea, northeast of the Madra Mountains, and south of Çandarlı Bay. Güre is a 
town on the Edremit Bay in the Edremit district, Balıkesir. The town of Edremit is $12 \mathrm{~km}$ away. The district is located in the Aegean region between Edremit Bay and Kazdaği. Küçükkuyu is a tourist town in Ayvacik, Çanakkale. Güre is located in the west of Altınoluk with Behramkale in the east and Ayvacık in the northeast. There is no river in the Güre-Küçükkuyu region, but there are the Edremit-Zeytinli, Kızılkeçili, Güre, and Altınoluk streams with a length of 6-10 km in this area. From these streams to the coastal section, mostly domestic wastewaters are present (Önce, 2014).

The location and location map of the study area are given in Figure 1. Three sea drilling samples were taken from the Güre (13.20 m - $16.00 \mathrm{~m})$, Küçükkuyu (13.00 m - 28.00 m), and Dikili (10.00 m - $19.00 \mathrm{~m}$ ) area with a modular sea bottom and semi-hydraulic drilling machine (Figure 2). The samples were brought to the laboratory in corrugated boxes which were not exposed to sunlight. A total of three samples were taken from the top, bottom and center sections of each drilling core. Total of 15 samples were examined from three drillings. The samples were analyzed in duplicate. The precision for TOC, TN, IC and $\mathrm{TC}$ was $\pm 0.02 \mathrm{wt} \%, \pm 0.01 \mathrm{wt} \%, \pm 0.01 \mathrm{wt} \%$ and $\pm 0.01 \mathrm{wt} \%$, respectively $(\mathrm{n}=5)$. The range of TOC-LCSH/CPH is $4 \mu \mathrm{g} / \mathrm{L}$ (ppb) - 30,000 mg/L (ppm).

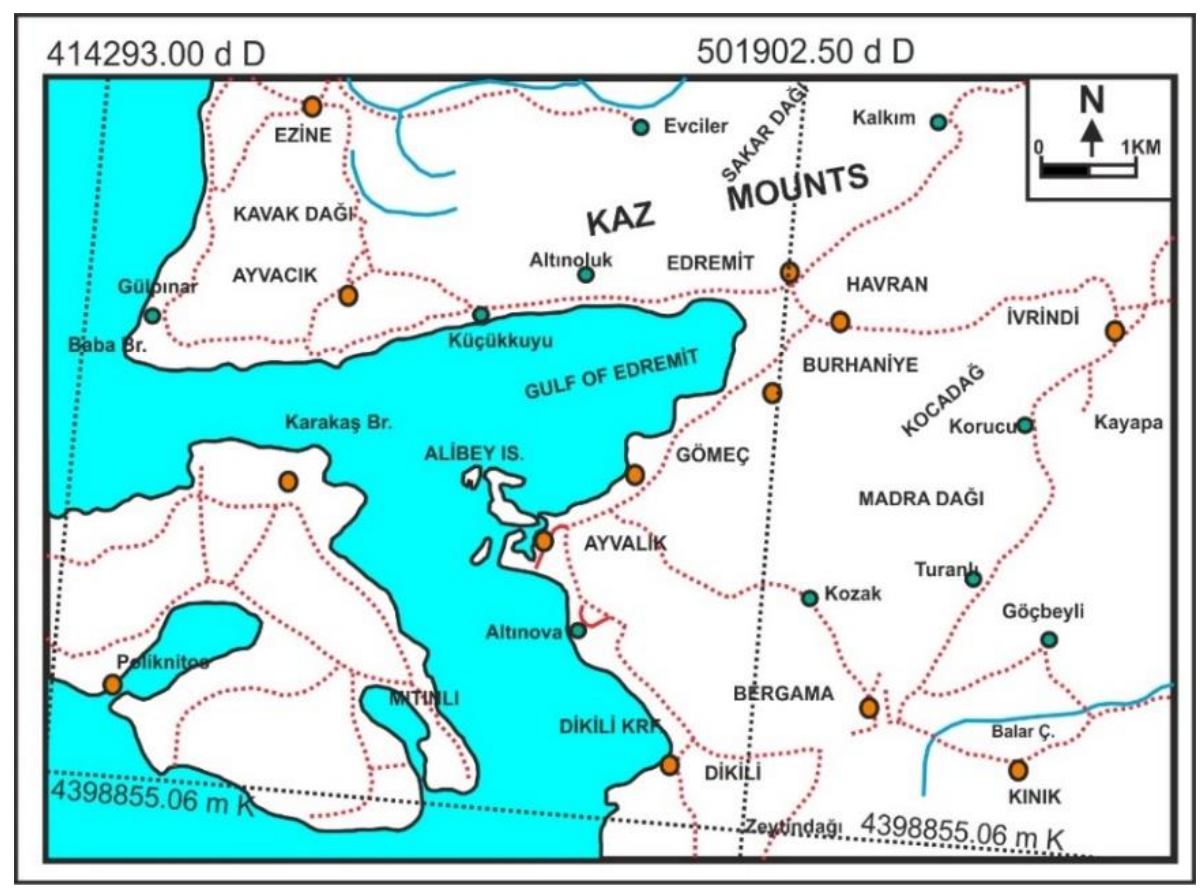

Figure 1. Map of study area and sampling points (Dikili BH-1, Güre BH-3, and Küçükkuyu $B H-3)$

The coordinates of the sample points were shown in Table 1. For the analysis of organic matter, 200 grams of sediment samples were taken from the cores with an average of $50 \mathrm{~cm}$ spacing (a long depth) and sent to Namik Kemal University Central Research Laboratory (NABILLTEM). A TOC-L series analyzer (Model SSM 5000 A) was used for the analysis of the total organic carbon in 15 samples collected along the drilling depth. TC, TOC, and IC measurements were made with this device. The concentrations of the samples collected at each $50 \mathrm{~cm}$ depth were divided by the number of samples collected along the selected depth to find the mean concentrations in each depth range. Total nitrogen (TN) measurements were performed to determine the $\mathrm{C} / \mathrm{N}$ ratio in the samples. 
Nitrogen measurement was performed with a Vapodest VAP 20s model device. In the measurement of TOC, both total carbon (TC) and inorganic carbon (IC) were measured. The total amount of organic carbon can be obtained by subtracting the amount of inorganic carbon from the total carbon content.

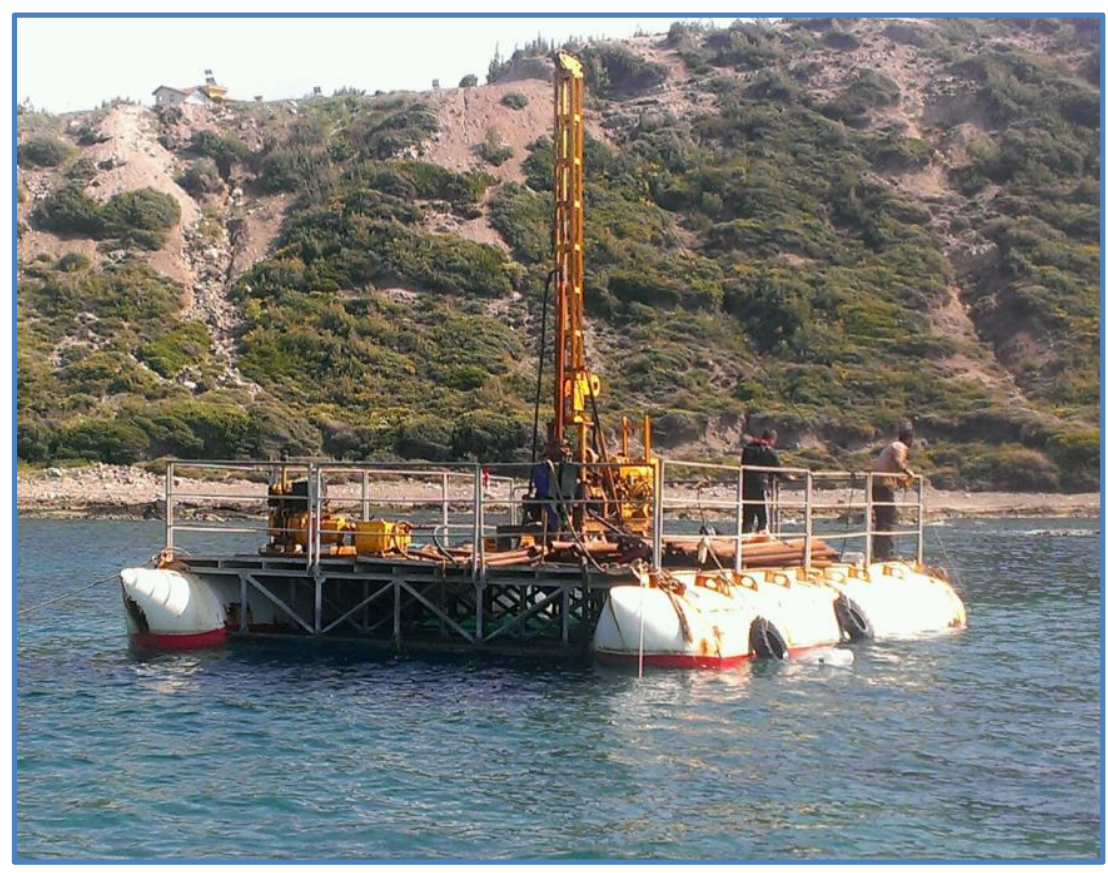

Figure 2. A view of Küçükkuyu BH3 and drilling machine

Table 1. The Coordinates of Bore Hole (BH1-Dikili, BH3-Güre and BH3-Küçükkuyu)

\begin{tabular}{c|c|c|c|c}
\hline \multirow{2}{*}{ Sample No } & \multicolumn{2}{|c|}{ Coordinates (WGS-84, 6 Deegre), 2016 } & $\begin{array}{c}\text { Driling depth } \\
(\mathbf{m})\end{array}$ & $\begin{array}{c}\text { Length Of sample } \\
(\mathbf{m})\end{array}$ \\
\cline { 2 - 5 } & East (Y) & North (X) & \multicolumn{2}{|c}{} \\
\hline Dikili (BH-1) & 490060.55 & 4324738.74 & $10.00-19.00$ & 9.00 \\
Güre (BH-3) & 489776.20 & 4381514.27 & $13.20-16.00$ & 2.80 \\
Küçükkuyu (BH-3) & 466009.22 & 4377155.44 & $13.00-28.00$ & 15.00 \\
\hline
\end{tabular}

\section{Results and Discussion}

Three soundings were made in the Aegean Sea by Yümün Mühendislik in Dikili (İzmir), Güre (Balıkesir), and Küçükkuyu (Çanakkale) regions, and cores obtained from drilling were used in this study. Five samples of sediment were collected from each core samples at the base, middle, and upper levels, and TOC, OC, IC, and TN concentrations were measured in the laboratory. Inland and marine pollutions were determined by taking into consideration the formation time of the precipitate.

Based on these analyzes, the TOC values were found to be high in Küçükkuyu and Güre. In Dikili, the TOC values obtained at the highest level of drilling were higher than at the lower part. Nitrogen values were generally high at the intermediate levels of the drillings. Previous studies have used the $\mathrm{C} / \mathrm{N}$ ratios used to monitor dominant carbon resources accumulated in coastal deposits (Zhang et al., 2007; Pan et al., 2019). Hence, 
we used $\mathrm{C} / \mathrm{N}$ ratios to characterize organic matter sources. In the samples taken from Edremit Bay, the TOC/N ratio was variable throughout the depth (increase/decrease), indicating that there was no pollution the result of the population concentration. The organic matter in the sediments is a mixture of materials. It is derived from particles caused by intra-continental erosion, and organic matter is produced from biological activity in the aquatic environment (Chen et al., 2008).

As can be seen in Figure 3, the samples taken from the sea bottom near Güre show the TC, IC, TOC, and TN analysis results. There was no linear relation between the TC, TOC, and IC parameters and depth. The TOC concentration varied between $8.14-16.40 \mathrm{~g} / \mathrm{kg}$ (0.814-1.64\%). Walinsky et al. (2009) found that the TOC content of sediments on the coast of Southeast Alaska ranged from $0.3-8 \%$ by weight.

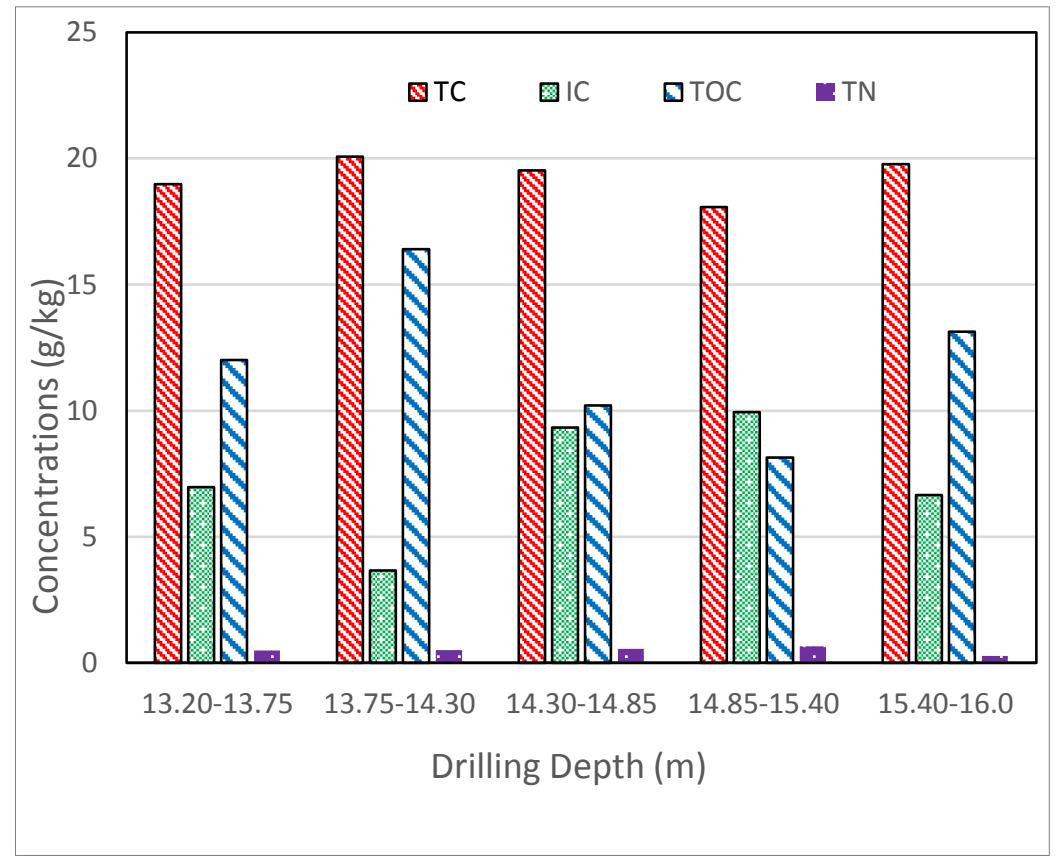

Figure 3. Total Carbon, Inorganic Carbon, Total Organic Carbon and Total Nitrogen concentration change depending on depth in Güre seabed drilling

When the surface and deeper samples were compared, no standard increase or decrease was found. Many researchers have reported that fine and coarse-grained clay and sand deposits were effective in changing TOC and TN concentrations (Keil et al.,1994; Ogrinc et al., 2005). The TOC concentration in the sample from the top layer was found to be $12.01 \mathrm{~g} / \mathrm{kg}$. The sediment deposition rate was $7.509 \mathrm{~mm} /$ year. As a result of the analysis of core samples taken from 13.75-14.30 m depth, the TOC concentration was found to be $16.40 \mathrm{~g} / \mathrm{kg}$. Considering the annual amount of sedimentation ( $\mathrm{Vs}=7.509 \mathrm{~mm} / \mathrm{year}$ ) and the population and agricultural structure of the region, this region was not contaminated by humans approximately 100 years ago. In this case, it was concluded that there is natural intra-continental pollution the result of total precipitation intensity. The lowest TOC concentration was measured in the sediment sample taken in the range of 14.85-15.40 m. The TOC concentration increased to $13.13 \mathrm{~g} / \mathrm{kg}$ in the sample taken at a depth of 15.40-16 m. High TOC showed that pollution was of inland origin (plant origin). Irizuki et al. (2015) conducted a study in Kasado Bay, all samples were below $20 \mathrm{mg} / \mathrm{g}$ TOC 
content and stated that eutrophication was not severe. At the same point, a very low total nitrogen concentration ( 0.28$)$ showed that pollution was not from organic matter of algae and marine plants. Algae contain high levels of nitrogen. At this sample point, the concentration of inorganic carbon in the samples taken at the depth was between $3.67-9.94 \mathrm{~g} / \mathrm{kg}$. IC concentrations did not show a linear increase or decrease over depth. The low total nitrogen $(0.28-0.49 \mathrm{~g} / \mathrm{kg})(0.028-0.049 \%)$ and TOC values compared to the other regions indicate that this area has greater biological activity in the seabed. The concentration of TC in the samples taken from the Güre BH-3 point varied between $18.08-20.07 \mathrm{~g} / \mathrm{kg}$. The total carbon values throughout the depth were $18.98 \mathrm{~g} / \mathrm{kg}$ $(13.20-13.75 \mathrm{~m}), 20.07 \mathrm{~g} / \mathrm{kg}(13.75-14.30), 19.53 \mathrm{~g} / \mathrm{kg}(14.30-14.85 \mathrm{~m}), 18.08 \mathrm{~g} / \mathrm{kg}$ $(14.85-15.40 \mathrm{~m})$ and $19.78 \mathrm{~g} / \mathrm{kg}(15.40-16 \mathrm{~m})$. The region was stable in terms of TC ratio (mean $19.288 \mathrm{~g} / \mathrm{kg}$ ). In the study conducted by Xu et al. (2017), TOC and TN values were found to be between 0.19-0.67 and 0.03-0.09. In another study conducted by Gao et al. (2008), the TOC content ranged from 0.86 to $1.60 \%$ of dry sediment weight and ranged from $1.25 \%$ on average. In a different study by Gao et al. (2008), total nitrogen content averaged $0.146 \%$ in the range $0.096-0.206 \%$ by weight of dry sediment.

At the Küçükkuyu BH-3 point, carrot samples were taken from the seabed at a depth of 13-28 m (Figure 4). Total nitrogen concentrations in this point were measured as 1.09, $1.34,1.12,1.57$ and $1.2 \mathrm{~g} / \mathrm{kg}$ at 13-16, 16-19-22, 22-25 and 25-28 m depths, respectively. The total nitrogen concentrations $(1.09-1.57 \mathrm{~g} / \mathrm{kg}$ ) were found to be highest in this region.

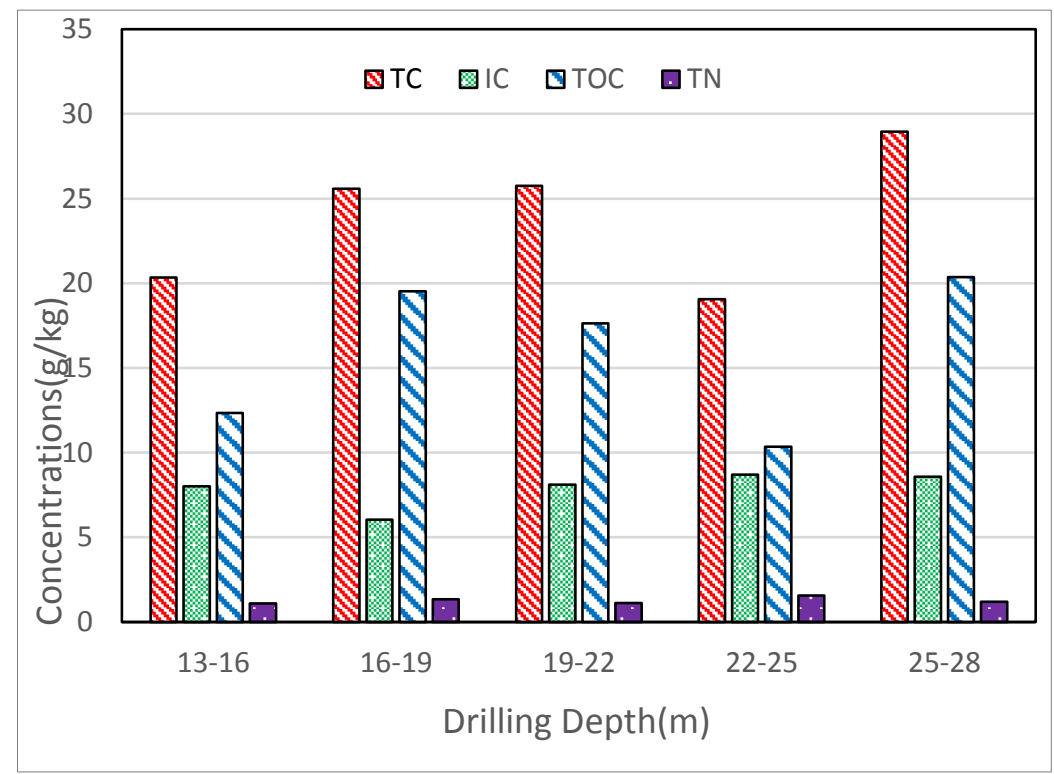

Figure 4. Total Carbon, Inorganic Carbon, Total Organic Carbon and Total Nitrogen concentration change depending on the depth of Küçükkuyu seabed drilling

The sedimentation rate at the Küçükkuyu BH-3 point was $5.743 \mathrm{~mm} / \mathrm{year}$. The TOC concentration ranged from 10.35 to $20.36 \mathrm{~g} / \mathrm{kg}$. The lowest and highest TOC values were in the last two layers. The high total nitrogen and TOC in this region indicated that both marine and continental pollution were present. Higher $\mathrm{C} / \mathrm{N}$ values may represent a greater portion of terrestrial organic matter (Chen et al., 2008). The inorganic carbon concentration varied between $6.05-8.71 \mathrm{~g} / \mathrm{kg}$. Güre and Küçükkuyu regions were similar in terms of IC concentrations. The TOC/TN ratio was greater than 10, except for one 
point. The high nitrogen and carbon concentrations in the sediment indicated that the biodegradation of carbonaceous and nitrogenous substances is slow, and, in this area, the nitrification and denitrification rate in the seabed is low. Otherwise, the nitrogen concentration should be lower. The TOC concentration in the sample taken from 13-16 m (top layer) was $12.34 \mathrm{~g} / \mathrm{kg}$. In the samples taken between 16-19 $\mathrm{m}$ and 19-22 $\mathrm{m}$, the TOC value was measured as 19.54 and $17.64 \mathrm{~g} / \mathrm{kg}$, respectively. The lowest TOC value $(10.35 \mathrm{~g} / \mathrm{kg})$ was found in the sample taken between $22-25 \mathrm{~m}$. In parallel with the current studies (Irizuki et al., 2015), it has been found that eutrophication has not occurred in this field. The TOC/TN ratio was found to be 6.53 at this point. In this period, it was concluded that there was no intra-continental pollution and limited biological activity at the sea bottom (high concentration of total nitrogen). The limited number of agricultural areas in the Küçükkuyu region indicated that high nitrogen concentrations measured in the sediments were the result of algae. Total carbon concentrations along the depth in the Küçükkuyu region were $20.35 \mathrm{~g} / \mathrm{kg}(13-16 \mathrm{~m}), 25.59 \mathrm{~g} / \mathrm{kg}(16-19 \mathrm{~m}), 25.76 \mathrm{~g} / \mathrm{kg}$ $(19-22 \mathrm{~m}), 19.06 \mathrm{~g} / \mathrm{kg}(22-25 \mathrm{~m})$ and $28.95 \mathrm{~g} / \mathrm{kg}(25-28 \mathrm{~m})$. The highest total carbon concentration was found in this region (mean $23.94 \mathrm{mg} / \mathrm{kg}$ ). Küçükkuyu region contains higher concentrations of TOC than Güre region. Küçükkuyu sediments contain less stabilized sludge than Güre region. The TOC and TN values measured in Küçükkuyu region were higher than those of Xia et al. (2019).

Figure 5 shows the variation of the TC, IC, TOC, and TN values in the samples taken from the BH3 point. Sediment samples were taken from the sea floor at depths of 10 to $19.0 \mathrm{~m}$.

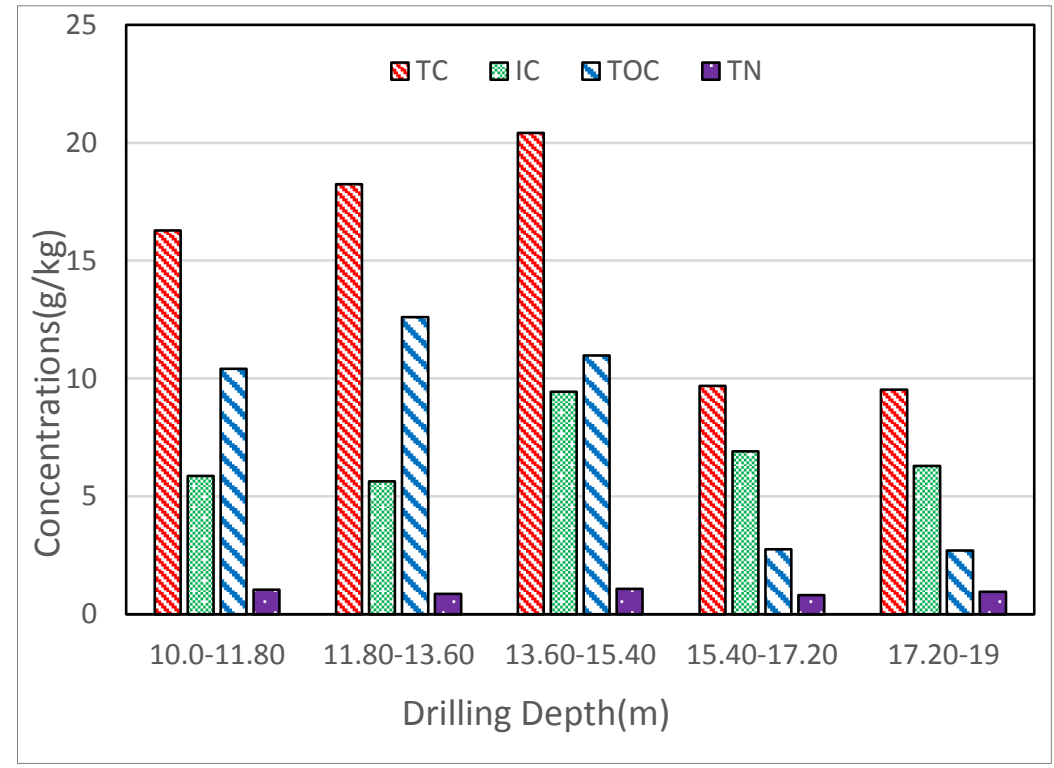

Figure 5. Total Carbon, Inorganic Carbon, Total Organic Carbon and Total Nitrogen concentration change depending on the depth of Dikili seabed drilling

The TOC value ranged between 2.71-12.60 g/l. The value here is in good agreement with the findings of Gao et al. (2008) and Xu et al. (2017). The TOC concentration was found to be 2.71 and 2.76 for 15.40-19 meters. Normally, a value of 6-8 represents a root of predominantly marine origin for the organic matter (Aitkenhead et al., 2000). It was very low compared to the upper sediment layers, showing that terrestrial and marine 
pollution was minimum. The lowest IC concentration $(5.64-9.43 \mathrm{~g} / \mathrm{kg}$ ) was found at this point. Sedimentation rate in this area was $1.217 \mathrm{~mm} / \mathrm{year}$. The high levels of TOC in the upper layers indicated that intra-continental (carbon from high plants) and marine pollution (marine plants) is high. Low TOC concentration $(<20 \mathrm{mg} / \mathrm{g})$ indicated that there was no eutrophication in this area (Irizuki et al., 2015). The main mechanism for algae growth was the nutrient increase caused by river currents and floods. As a result of nutrient growth, excessive algae growth occurs. Algae growth results in an increase in organic carbon in sediments (Yamamuro et al., 2005; Zhang et al., 2009). The time of formation of the top two layers corresponded to 2958 years. TC concentration increases as the depth increases and decreases again after a certain point. Total carbon concentrations along the depth were $16.28 \mathrm{~g} / \mathrm{kg}(10-11.80 \mathrm{~m}), 18.24 \mathrm{~g} / \mathrm{kg}(11.80-13.60$ $\mathrm{m}), 20.41 \mathrm{~g} / \mathrm{kg}(13.60-15.40 \mathrm{~m}), 9.678 \mathrm{~g} / \mathrm{kg}(15.40-17.20 \mathrm{~m})$, and $9.52 \mathrm{~g} / \mathrm{kg}(17.20-19.0$ $\mathrm{m})$, respectively. This is the result of the high IC concentration at this point. The total nitrogen concentration has different values throughout the depths. A specific increase or decrease in these sample points was not noted. The TN concentration ranged from 0.81 to $1.89 \mathrm{~g} / \mathrm{kg}$. Inland pollution originating from the continent (high plant carbon) was dominant at the depth of 11.80-13.60 (1479 years). High nitrogen concentrations at the sample points indicated that biological degradation (nitrification and denitrification) was poor. Previous studies have shown that degradation of organic matter is most active near the water sludge interface (Middelburg et al., 1993; Niggemann et al., 2006). In region Dikili, higher TOC values were found in the upper layers and decreased towards the lower layers.

In order to make a regional comparison, the correlation graphs of the percentages of TN, TC, IC, and TOC values of the drilling samples taken in Dikili, Güre, and Küçükkuyu were given along with their depths in Figure 6.

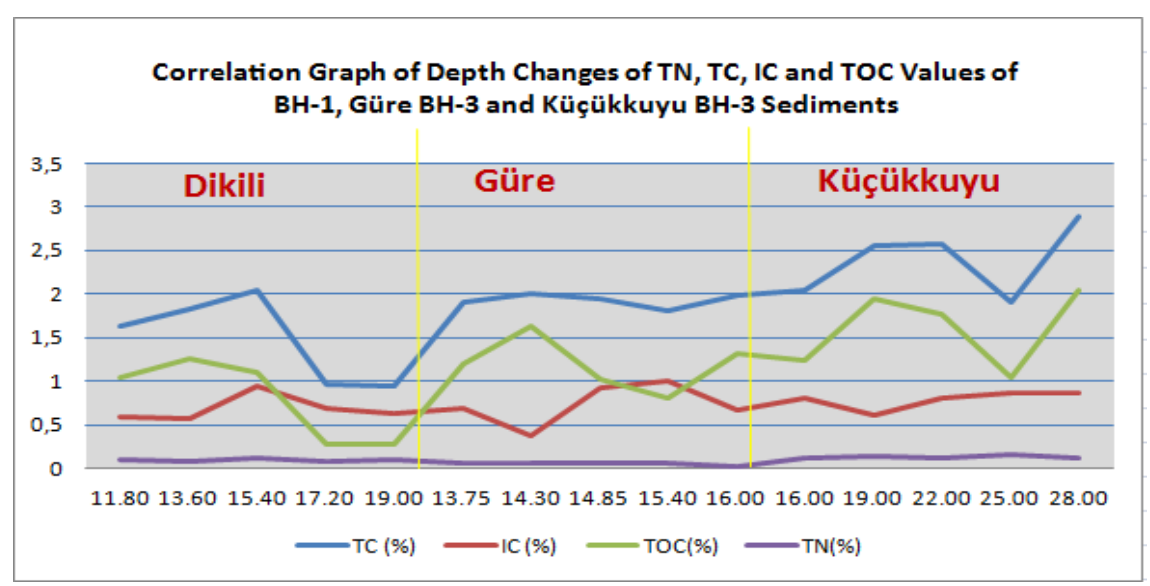

Figure 6. Correlation Graph of Depth Variations of TN, TC, IC and TOC Values of Dikili BH-1, Gure BH-3 and Küçükkuyu BH-3 Sediments

As can be seen in Figure 6, TOC values were higher in the Küçükkuyu region (10.35$20.36 \mathrm{~g} / \mathrm{kg}$ ) than Dikili $(2.71-12.6 \mathrm{~g} / \mathrm{kg})$ and Güre $(8.14-16.4 \mathrm{~g} / \mathrm{kg})$. In terms of heavy metal concentrations, these sample points represent a clean environment when compared to the Pollution Index (PI) map made by Yümün and Önce (2017). In the Küçükkuyu, Dikili, and Güre regions, it was observed that the terrestrial and marine nitrogen sources were similar over a long period of time. When the BH1 (Dikili) $(0.81-1.08 \mathrm{~g} / \mathrm{kg}$ ), BH3 
(Küçükkuyu) (1.09-1.57 g/kg) and BH3 (Güre) (0.28-0.66 g/kg) regions were compared, the lowest nitrogen concentrations were found in the $\mathrm{BH} 3$ (Güre) region. Unlike Chen et al. (2008), there was no linear relationship between TOC and nitrogen exchange in this study. Total nitrogen, total organic carbon and inorganic carbon concentrations increased in Küçükkuyu region and therefore the increase in total carbon concentration was highest in this area (Figure 6). As seen from the curve, the total carbon concentration increased gradually from Dikili to Güre and Küçükuyu. Küçükkuyu region has steep mountainous and rich vegetation. TOC and total nitrogen concentrations were considered to be high due to the high intra-continental transport.

Unlike organic carbon, inorganic carbon (IC) values were seen equally in all three regions. The similarity of these values shows that the sources of inorganic carbon from the terrestrial area are similar. Considering that the seabed sediments were formed over more than 2000 years, it was determined that organic pollution was not related to the existing industry and population.

As a result of drilling on the sea floor in the Güre region, the TOC/TN ratios were found to be 24.61 at a drilling depth of 13.20-13.75 meters (Figure 7).

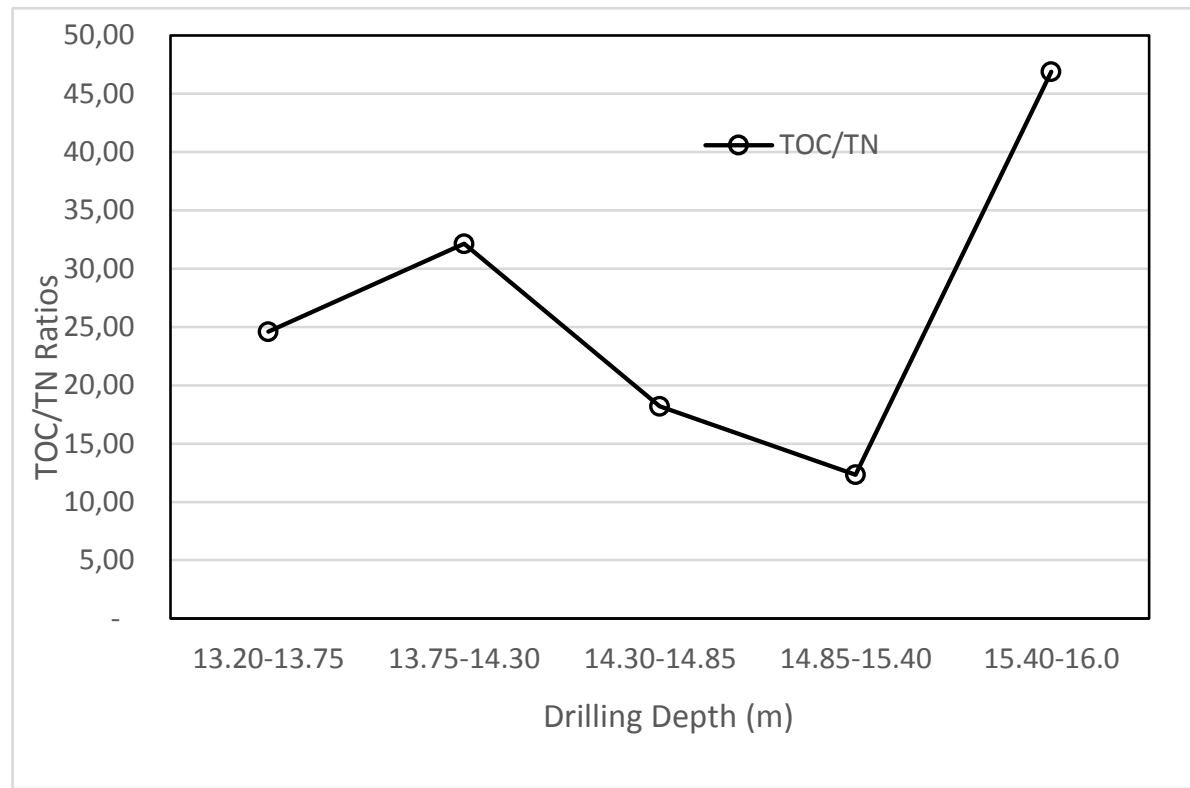

Figure 7. Change of TOC/TN ratios depending on the depth of drilling in the deep sea bottom(Güre)

It was found that intra-continental pulural (plant origin) was intense in this area. The intra-continental organic pollution $(\mathrm{TOC} / \mathrm{TN}=32.16)$ in the sediment layer of 13.7514.30 meters increased. At 14.85-15.40 meters sediment thickness, the TOC/TN ratio decreased to 12.33 . In the 220 -year period required for precipitation formation in this thickness, the transport of intra-continental organic matter (plant origin) decreased considerably. In the 15.40 - 16.0 meter sediment range (80 years), the increase in intracontinental organic matter was found to be very high $(\mathrm{TOC} / \mathrm{TN}=46.89)$. Intracurrent contamination increased towards the upper layers of the sediment. Higher $\mathrm{C} / \mathrm{N}$ values may represent the proportion of organic matter originating mainly from terrestrial areas (Chen et al., 2008). As a result, it was thought that transport of organic matter was carried out in certain periods of time although there were no rainfall records for that period. The 
TOC/TN (12.33-46.89) ratios measured in this area (Güre) were much higher than similar studies (Xu et al., 2017; Xia et al., 2019). In the Güre region, the TOC/TN ratios were measured 24.61 (13.20-13.75 m), $32.16(13.75-14.30 \mathrm{~m}), 18.21(14.30-14.85 \mathrm{~m}), 12.33$ $(14.85-15.40 \mathrm{~m})$ and $46.89(15.40-16.0 \mathrm{~m})$ along the depth, respectively. In this area (Güre), the TOC/TN ratio varied between 12.33-46.89. On the coast of Southeast Alaska, these values $(\mathrm{C} / \mathrm{N})$ ranged from 7.7 to 12.7 (Walinsky et al., 2009). The average TOC/TN ratio in the Güre region (26.84) was much higher than in the seas such as Jiaozhou Bay (11.48) (Kang et al., 2017), Yellow Sea (7.99) (Limin et al., 2013), East China Sea (7.14) (Limin et al., 2012; Dong et al., 2015). The TOC/TN ratio of the samples taken at 13-16 meters depth in Küçükkuyu region was approximately the same as the samples taken at depths of 14.85-15.40 $\mathrm{m}$ in Güre region.

TOC/TN values in the Küçükkuyu region were measured as 11.32 (13-16 m), 14.58 (16-19 m), 14.46 (19-22 m), 6.52 (22-25 m), $16.97(25-28 \mathrm{~m})$. The TOC/TN ratio was found to be 11.32 at the 13-16 meter sediment depth in Küçükkuyu Bay (Figure 8).

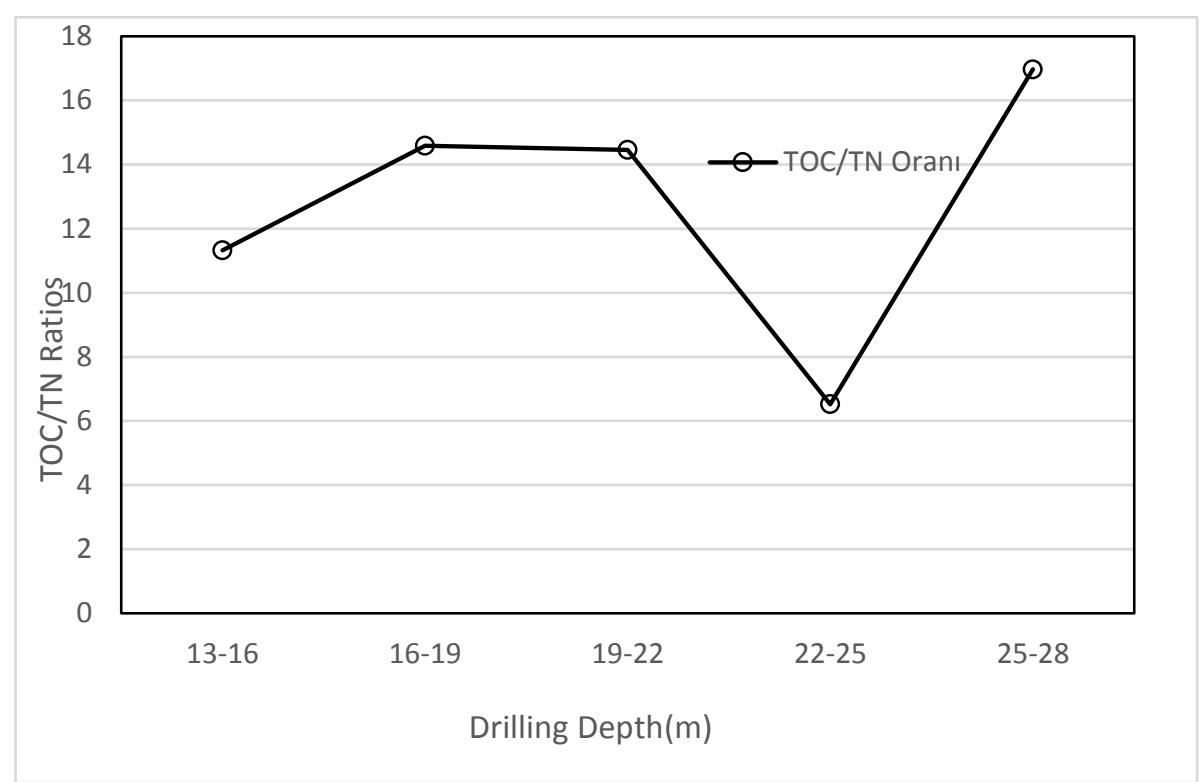

Figure 8. Change of TOC/TN ratios depending on drilling depth in Küçükkuyu seabed

The TOC/TN ratio in the sediment range of 16-22 meters remained constant at 14 . The $\mathrm{C} / \mathrm{N}$ ratio in sediments was used to investigate the sources and cycles of organic materials (Azevedo, 2003; Chen et al., 2008). A TOC/TN ratio of 14 indicates continental pollution (Meyers et al., 1984). In accordance with the current literature, this period of precipitation was dominated by inland organic matter (plant origin). The TOC/TN ratio decreased rapidly in the time of $22-25 \mathrm{~m}$ precipitate formation. The TOC/TN ratio was 6.52 . Since the sedimentation rate was $5.743 \mathrm{~mm} /$ year in this region, the organic matter transport remained constant over a period of 500 years. Bacteria play a critical role in the transformation and mineralization of organic carbon and nitrogen in marine sediments (Kawasaki et al., 2006). For the drilling depth of 25-28 m, the TOC/TN ratio was measured as 16.97. In this time period, it was concluded that intra-continental organic matter transport (from high plants) was more dominant than the marine environment. The average TOC/TN ratio in the Küçükkuyui region (12.77) was similar to the Jiaozhou Bay (11.48) (Kang et al., 2017). The TOC/TN ratio in this region was higher than in the seas 
such as Yellow Sea (7.99) (Limin et al., 2013) and East China Sea (7.14) (Limin et al., 2012; Dong et al., 2015). At this point, intra-continental pollution increased towards the upper layers of the sediment. The TOC/TN ratio of the samples taken at 13-22 meters depth in Küçükkuyu region was approximately the same as the samples taken at depths of 11.80-13.60 $\mathrm{m}$ in Dikili region.

The TOC/TN change in the Dikili area depending on the drill depth was shown in Figure 9. The TOC/TN ratio was found to be high in the precipitated upper layers. The $\mathrm{TOC} / \mathrm{TN}$ ratio decreased as the sample depth increased.

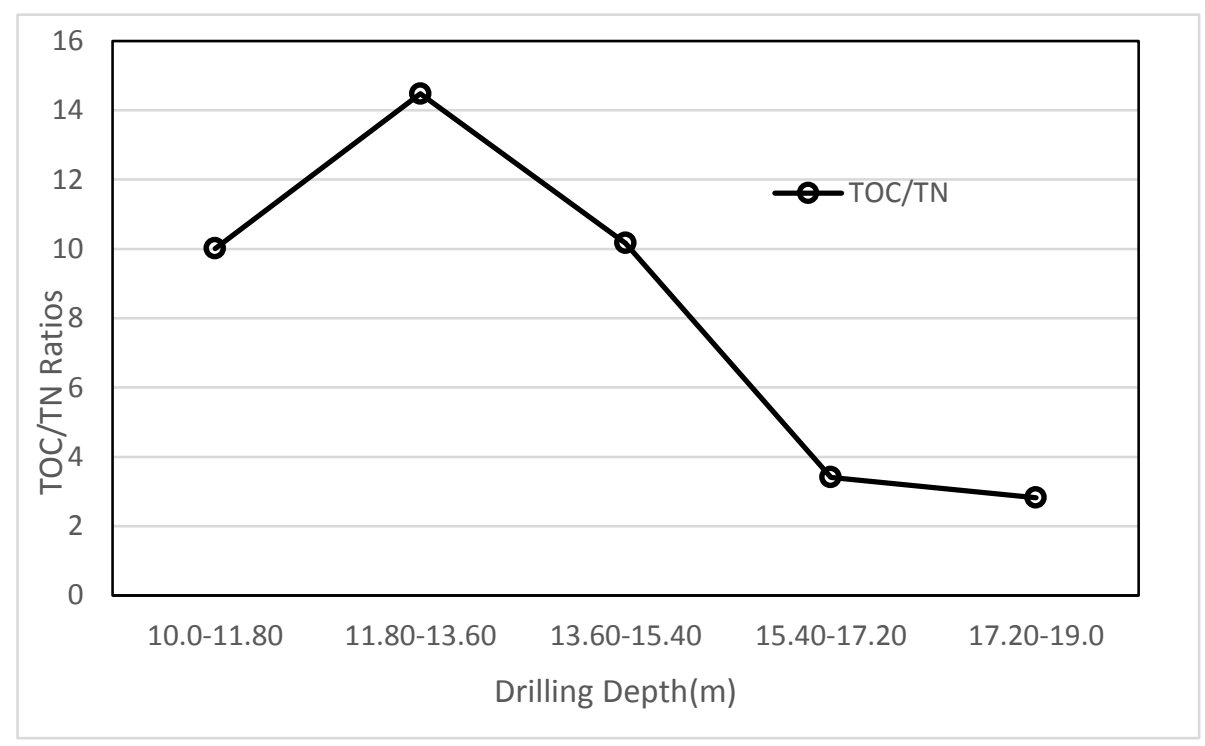

Figure 9. Change of TOC/TN ratios depending on drilling depth in Dikili seabed

The TOC/TN ratio was found to be 10.01 at the drilling depth of $10-11.80$ meters. In the upper section, it was determined that the source of organic matter originated from the sea's own structure (biological activity). The TOC/TN ratio was measured as 14.48 at the drilling depth of 11.80-13.60 m. C/N ratios showed different distribution ratios depending on depth. The source of organic matter was found to be marine and terrestrial (Venkatesan et al., 1987). Since the sediment deposition rate in this area was $1.217 \mathrm{~mm} / \mathrm{year}, 1479$ years was required for 1.8 meters of sediment formation. In this period, intra-continental pollution caused by terrestrial plants increased. The TOC/TN ratio was found to be 2.82 at a drilling depth of 17.20-19.0 meters. It has been found that the transport of intracontinental organic matter in this period of precipitation was very low. The decrease in TOC/TN ratios was the result of the contribution of marine algae (Liu et al., 2012). In this area, the TOC/TN ratios measured in deeper layers were found to be lower than other researchers (Walinsky et al., 2009; Xia et al., 2019). The average TOC/TN ratio in the Dikili region (8.178) was similar to that in the seas such as Jiaozhou Bay (11.48) (Kang et al., 2017), Yellow Sea (7.99) (Limin et al., 2013), East China Sea (7.14) (Limin et al., 2012; Dong et al., 2015). At this point, although the TOC/TN ratio increases towards the upper layers, the TOC/TN ratio does not show intra-continental pollution. Dikili district has less rugged terrain compared to the other two sample areas. Therefore, the sediment formation rate was quite small compared to other regions due to the low intra-continental transport. 


$$
-14762 \text { - }
$$

\section{Conclusion}

TC, TOC, IC and total nitrogen measurements were carried out in Edremit Bay (Küçükkuyu, Güre, and Dikili). As a result of these measurements, TOC/TN ratios were found depending on the depth of the drilling. The total nitrogen concentrations in the Küçükkuyu region ranged from 1.09 to $2.1 \mathrm{~g} / \mathrm{kg}$. The total nitrogen concentration increased throughout the drilling depth. It was concluded that this was the result of nitrogen-rich algae activity in the marine environment. TOC concentrations were 12.34-20.36, 12.01-13.13, and 2.71-10.41 gr/kg in Küçükkuyu, Güre, and Dikili marine sediments, respectively. The biodegradation of organic matter and the nitrogen accumulated in the sea floor in Kucukkuyu Bay was low. It was thought that nitrogencontaining organic substances could not be converted to nitrate the result of the oxygen limitation in Küçükkuyu sediments, and, thus, denitrification did not take place.

The decrease in total nitrogen concentration along the depth of the seabed in the Güre region indicated that nitrification and denitrification reactions occur. The decrease of TOC and TN in the depth in the Dikili region indicated that denitrification is performed in the base sediments. The highest TOC/TN ratio was measured at 46.89 at a $15.40-16.0 \mathrm{~m}$ depth at the Güre DS3 point. The lowest TOC/TN ratio was found to be 2.82 in Dikili $\mathrm{BH} 1$. At the $\mathrm{BH} 3$ point in Güre, the TOC/TN increased throughout the depth indicating organic pollution from terrestrial high plants. According to Meyers et al. (1984), if the TOC/TN ratio is between $12-14$, it is a terrestrial source of organic matter. It can be concluded that terrestrial pollution prevails in the Güre region. Venkatesan et al. (1987) indicated that organic matter had a planktonic origin if the ratio of TOC/TN was between 6 and 8. At the depth of $15-19 \mathrm{~m}$ at the Dikili BH1 point, the organic matter was found to be of marine origin. At other points, terrestrial and marine organic matter formation was observed.

The TC concentration is equal to the sum of IC and TOC. The highest total carbon content was observed in Küçükkuyuda and the lowest in the Dikili region. TC content was found between 19.06-28.95 in the Küçükkuyu region, between 18.08-20.07 in the Güre region, and between 9.52-20.41 in the Dikili region. In the future study, $\delta 13 \mathrm{C}$, and $\delta 15 \mathrm{~N}$ isotopic parameters should be measured in this area. In addition, in-continental soil samples should also be examined. The research area should be carried out in a wider area and at more sample points.

\section{REFERENCES}

[1] Aitkenhead, J. A., McDowell, W. H. (2000): Soil C: N ratio as a predictor of annual riverine DOC flux at local and global scales. - Global Biogeochemical Cycles 14: 127-138.

[2] Avramidis, P., Nikolaou, K., Bekiari, V. (2015): Total Organic Carbon and Total Nitrogen in Sediments and Soils: A Comparison of the Wet Oxidation - Titration Method with the Combustion-Infrared Method. - Agriculture and Agricultural Science Procedia 4: 425-430.

[3] Azevedo, D. A. (2003): A preliminary investigation of the polar lipids in recent tropical sediments from aquatic environments at Campos dos Goytacazes. - Journal of the Brazilian Chemical Society 14: 97-106.

[4] Bartoli, G., Papa, S., Sagnella, E., Fioretto, A. (2012): Heavy metal content in sediments along the Calore river: relationships with physical-chemical characteristics. - Journal of Environmental Management 95: 9-14. 


$$
-14763 \text { - }
$$

[5] Bayram, A., Önsoy, H., Akinci, G., Bulut, V. N. (2011): Variation of total organic carbon content along the stream Harsit, Eastern Black Sea Basin, Turkey. - Environmental Monitoring and Assessment 182(1-4): 85-95.

[6] Chen, F., Zhang, L., Yang, Y., Zhang, D. (2008): Chemical and isotopic alteration of organic matter during early diagenesis: Evidence from the coastal area off-shore the Pearl River estuary, south China. - Journal of Marine Systems 74: 372-380.

[7] De Souza, J. R. B., de Rosario Zucchi, M. R., Costa, A. B., Azevedo, A. E. G., Spano, S. (2017): Geochemical markers of sedimentary organic matter in Todos os Santos Bay, Bahia - Brazil. Indicators of sources and preservation. - Marine Pollution Bulletin 119: 239-246.

[8] Dong, L., Peng, Y., Bianchi, T. S. (2015): Historical reconstruction of organic carbon inputs to the East China Sea inner shelf: Implications for anthropogenic activities and regional climate variability. - The Holocene 25(12): 1869-1881.

[9] Gao, X., Chen, S., Long, A. (2008): Composition and sources of organic matter and its solvent extractable components in surface sediments of a bay under serious anthropogenic influences: Daya Bay, China. - Marine Pollution Bulletin 56: 1066-1075.

[10] Hecky, R. E., Campbell, P., Hendzel, L. L. (1993): The stoichiometry of carbon, nitrogen, and phosphorus in particulate matter of lakes and oceans. - Limnology and Oceanography 38(4): 709-724.

[11] Irizuki, T., Ito, H., Sako, M., Yoshioka, K., Kawano, S., Nomura, R., Tanak, Y. (2015): Anthropogenic impacts on meiobenthic Ostracoda (Crustacea) in themoderately polluted Kasado Bay, Seto Inland Sea, Japan, over the past 70years. - Marine Pollution Bulletin 91: 149-159.

[12] Jacob, J., Jayaraj, K. A., Rehman, H. H., Chandramohanakumar, N., Balachandran, K. K., Raveendran, T. V., Joseph, T., Nair, M., Achuthankutty, C. T. (2009): Biogeochemical characteristics of the surface sediments along the western continental shelf of India. Chemistry and Ecology 25(2): 135-149.

[13] Kang, X., Song, J., Yuan, H., Li, X., Li, N., Duan, L. (2017): The sources and composition of organic matter in sediments of the Jiaozhou Bay: implications for environmental changes on a centennial time scale. - Acta Oceanologica Sinica 36(11): 68-78.

[14] Kawasaki, N., Benner, R. (2006): Bacterial release of dissolved organic matter during cell growth and decline: molecular origin and composition. - Limnology and Oceanography 51: 2170-2180.

[15] Keil, R. G., Tsamakis, E., Fuh, C. B., Giddings, J. C., Hedges, J. I. ( 1994): Mineralogical and texture controls on the organic composition of coastal marine sediments: Hydrodynamic separation using SPLITT-fractionation. - Geochemica et Cosmochimica Acta 58: 879-893.

[16] Koziorowska, K., Kuliński, K., Pempkowiak, J. (2016): Sedimentary organic matter in two Spitsbergen fjords: Terrestrial and marine contributions based on carbon and nitrogen contents and stable isotopes composition. - Continental Shelf Research 113: 38-46.

[17] Lallier-Verges, E., Perrussel, B. P., Disnar, J. R., Baltzer, F. (1998): Relationships Between Environmental Conditions and The Diagenetic Evolution of Organic Matter Derived from Higher Plants İn A Modern Mangrove Swamp System (Guadeloupe, French West Indies). - Organic Geochemistry 29(5-7): 1663-1686.

[18] Limin, H., Xuefa, S., Zhigang, Y. (2012): Distribution of sedimentary organic matter in estuarine-inner shelf regions of the East China Sea: implications for hydrodynamic forces and anthropogenic impact. - Marine Chemistry 142-144: 29-40.

[19] Limin, H., Xuefa, S., Zhigang, G. (2013): Sources, dispersal and preservation of sedimentary organic matter in the Yellow Sea:the importance of depositional hydrodynamic forcing. - Marine Geology 335: 52-63.

[20] Liu, X., Ge, C. (2012): Spatial and temporal variations of sedimented organic matter in Xiaohai Lagoon, Hainan Island. - Acta Oceanologica Sinica 31(3): 74-86.

[21] Martinez-Santos, M., Probst, A., García-García, J., Ruiz-Romera, E. (2015): Influence of anthropogenic inputs and a high-magnitude flood event on metal contamination pattern in 


$$
-14764 \text { - }
$$

surface bottom sediments from the Deba River urban catchment. - Science of the Total Environment 514: 10-25.

[22] Meyers, P. A., Leenheer, M. J., Eaoie, B. J., Maule, S. J. (1984): Organic Geochemistry of Suspended and Settling Particulate Matter İn Lake Michigan. - Geochim. Cosmochim Acta 48: 443-452.

[23] Middelburg, J. J., Vlug, T., Jaco, F., Van der Nat, W. A. (1993): Organic matter mineralization in marine systems. - Global and Planetary Change 8(1-2): 47-58.

[24] Niggemann, J., Schubert, C. J. (2006): Fatty acid biogeochemistry of sediments from the Chilean coastal upwelling region: sources and diagenetic changes. - Organic Geochemistry 37: 626-647.

[25] Ogrinc, N., Fontolan, G., Faganeli, J., Covelli, S. (2005): Carbon and nitrogen isotope compositions of organic matter in coastal marine sediments (the Gulf of Trieste, N Adriatic Sea): indicators of sources and preservation. - Marine Chemistry 95(3-4): 163-181.

[26] Önce, M. (2014): Güre (Edremit/Balıkesir) ile Küçükkuyu (Ayvacık/Çanakkale) Arasında Ege Denizi'ndeki Ağır Metal Kirliliğinin Yayılımı ve Foraminiferler Üzerindeki Etkilerinin Araştırılması. - Namık Kemal Üniversitesi Fen Bilimleri Enstitüsü Yüksek lisans Tezi, Tekirdăg.

[27] Pan, Z., Gao, Q. F., Dong, S. L., Wang, F., Li, H. D., Zhao, K., Jiang, X. Y. (2019): Effects of a balone (HaliotisdiscushannaiIno) andkelp (Saccharinajaponica) mariculture on sources, distribution, and preservation of sedimentaryorganic carbon in Ailian Bay, China: Identified by coupling stable isotopes $(\delta 13 \mathrm{C}$ and $\delta 15 \mathrm{~N})$ with $\mathrm{C} / \mathrm{N}$ ratio analyses. - Marine Pollution Bulletin 141: 387-397.

[28] Sampaio, L., Rodrigues, A. M., Quintino, V. (2010): Carbon and Nitrogen Stable İsotopes İn Coastal Benthic Populations Under Multiple Organic Enrichment Sources. - Marine Pollution Bulletin 60: 1790-1802.

[29] Stein, R. (1991): Accumulation of Organic Carbon in Marine Sediments. - Lecture Notes in Earth Sciences 34, Springer -Verlag.

[30] Venkatesan, M. I., Kaplan, I. R. (1987): The Lipid Geochemistry of Antarctic Marine Sediments: Bransfield Strait. - Marine Chemistry 21: 347-375.

[31] Visco, G., Campanella, L., Nobili, V. (2005): Organic carbons and TOC in waters: an overview of the international norm for its measurements. - Microchemical Journal 79(12): $185-191$.

[32] Walinsky, S. E., Prahl, F. G., Mix, A. C., Finney, B. P., Jaeger, J. M., Rosen, G. P. (2009): Distribution and composition of organic matter in surface sediments of coastal Southeast Alaska. - Continental Shelf Research 29: 1565-1579.

[33] Waterson, E. J., Canuel, E. A.(2008): Sources of Sedimentary Organic Matter İn The Mississippi River and Adjacent Gulf of Mexico As Revealed by Lipid Biomarker and $\mathrm{D}^{13}$ $\mathrm{C}_{\text {toc }}$ Analyses. - Organic Geochemistry 39: 422-439.

[34] Wei, W., Shiqi, Z., Youliang, J. (2006): Evolution and controlling factor of the circumJiaozhou Bay coastline. - Marine Geology Letters (in Chinese) 22(9): 7-10.

[35] Winogradow, A., Pempkowiak, J. (2018): Characteristics of sedimentary organic matter in coastal and depositional areas in the Baltic Sea. - Estuarine, Coastal and Shelf Science 204: 66-75.

[36] Xia, B., Han, Q., Chen, B., Sui, Q., Jiang, T., Sun, X., Zhu, L., Chai, C., Qu, K. (2019): Influence of shellfish biodeposition on coastal sedimentary organic matter: A case study from Sanggou Bay, China. - Continental Shelf Research 172: 12-21.

[37] Xu, G., Liua, J., Hu, G., Jonell, T. N., Chen, L. (2017): Distribution and source of organic matter in surface sediment from the muddy deposit along the Zhejiang coast, East China Sea. - Marine Pollution Bulletin 123: 395-399.

[38] Yamamuro, M., Kanai, Y. (2005): A 200-year record of natural and anthropogenic changes in water quality from coastal lagoon sediments of Lake Shinji, Japan. - Chemical Geology 218(1-2): 51-61. 


$$
-14765-
$$

[39] Yümün, Z. Ü., Önce, M. (2017): Monitoring heavy metal pollution in foraminifera from the Gulf of Edremit (northeastern Aegean Sea) between Izmir, Balıkesir and Çanakkale (Turkey). - Journal of African Earth Sciences 130: 110-124.

[40] Zetsche, E., Thornton, B., Midwood, A. J., Witte, U. (2011): Utilization of different carbon sources in a shallow estuary identified through stable isotope techniques. - Cont. Shelf Res 31: 832-840.

[41] Zhang, J., Wu, Y., Jennerjahn, T. C., Ittekkot, V., He, Q. (2007): Distribution of organic matter in the Changjiang (Yangtze River) Estuary and their stable carbon and nitrogen isotopic ratios: Implications for source discrimination and sedimentary dynamics. - Marine Chemistry 106: 111-126.

[42] Zhang, L., Yin, K., Wang, L., Chen, F., Zhang, D., Yang, Y. (2009): The sources and accumulation rate of sedimentary organic matter in the Pearl River Estuary and adjacent coastal area, Southern China. - Estuarine, Coastal and Shelf Science 85: 190-196. 